\title{
Exploration and Thoughts on the Protection and Inheritance of the Eight Unique Skills of Yanjing: Taking Beijing Palace Carpets as an Example
}

\author{
Xu Jiang ${ }^{1, *}$ Baitao Jiang ${ }^{2}$ \\ 1,2 Beijing Information Technology College, Beijing, China \\ *Corresponding author. Email: jiangx@bitc.edu.cn
}

\begin{abstract}
The technique of palace carpet weaving has been introduced to the people for more than one hundred years, and Beijing palace carpets have also entered the homes of ordinary people from imperial possessions. From the widespread popularity in China and foreign countries in the 1970s and 1980s, to the impact of consumer concepts, aesthetic concepts, life concepts, and woven carpets in the 1990s, it gradually faded out of public view. Since the beginning of the new century, Huafang Carpet Art Co., Ltd. (formerly Beijing No. 5 Carpet Factory) has taken a series of measures such as the restoration of the Panjin weaving process to the certification of intangible heritage, which has brought the development of Beijing Palace carpet weaving technology to a new level, but it is far from achieving self-growth without protection. This article takes Beijing palace carpets as an example, analyzes the status quo and causes of the protection and inheritance of Beijing palace carpets, and discusses the effective protection of Beijing palace carpet weaving techniques from the aspects of cultural ecological construction, intangible cultural heritage industrialization, and innovative inheritance, aiming to realize the sustainable development of the protection and inheritance of intangible cultural heritage in arts and crafts.
\end{abstract}

Keywords: Intangible cultural heritage, Cultural ecology, Intangible cultural heritage industrialization, Innovative inheritance.

\section{INTRODUCTION}

The Beijing palace carpet, one of the eight unique skills in Yenching, is an important representative of traditional handicrafts in Chinese court art. Its pattern and ornamentation have distinctive artistic characteristics of Ningxia, Xinjiang, Tibet and other places, and it also contains auspicious cultural elements from all parts of the Central Plains. Its weaving skills are made of the best of all the places, fully embodying the splendid contrast of traditional Chinese culture and Beijing court art. In 2008, Beijing Palace carpet weaving technology was selected as the traditional handicraft carpet weaving technology project of the "Second Batch of National Intangible Cultural Heritage List", rejuvenating this traditional handicraft. However, due to the long production cycle of manual weaving of Beijing palace carpets, its living space is shrinking under the impact of modern carpet industry, and there are many difficulties and challenges in protection and inheritance research.

\section{THE PREDICAMENT AND REASONS FACED BY THE PROTECTION AND INHERITANCE OF BEIJING PALACE CARPET WEAVING SKILLS}

\subsection{The Inheritance and Protection of Beijing Palace Carpet Weaving Skills Lack the Support of Cultural Ecology}

First of all, the inheritance and continuation of a skill cannot be separated from the support of cultural ecology. The traditional handicraft of Beijing palace carpet, which relies on palace 
culture, loses the cultural ecological environment on which it depends when the palace culture exits the historical stage. Secondly, the change of lifestyle and the optimization of the living environment made the Beijing palace carpet lose its "practical" value for keeping warm and cold. In addition, the labor cost of hand-woven carpets and the high maintenance used were also the main factors that later became unsustainable for Beijing palace carpets. Besides, changes in consumer concepts and aesthetic appeal have gradually transformed people's use of carpets from the perspective of rigid demand and inheritance into fast-moving consumer goods and decorations. Taking the sales of carpets in the Swedish home furnishing brand IKEA as a reference, the fast, changing and fashionable lifestyle it claimed has brought a series of changes in aesthetic value and lifestyle. Compared with the "saving the old and no new" of Beijing palace carpets from the 1970s to the present, the Beijing No. 5 Carpet Factory to the present Huafang Carpet Art Co., Ltd. has made the Beijing palace carpet weaving skills return to the public's vision through a series of measures from the restoration of the panjin weaving technology to the recognition of intangible heritage skills, but the rescue efforts still cannot keep up with the deserted level of the palace carpet market, and the protection and inheritance of Beijing palace carpet weaving techniques still lack the effective support of cultural ecology.

\subsection{The Product Positioning Is Not Clear, and a Diversified Product System Has Not Been Formed}

"Long cycle, low production capacity, expensive materials, high price" — is the common problem of high price and low added value of handicraft intangible cultural heritage products, and it is also the main reason for the inaccurate positioning of the "marketization" of Beijing palace carpet products. On the one hand, the core skills of Beijing palace carpets are tufting and panjin. Because the raw materials required for weaving panjin carpets are expensive and expensive, and due to technical limitations, they cannot be massproduced. At one time, due to the lack of sophisticated raw materials and the difficulty of forming social demand, the Panjin weaving skills were lost after being introduced to the people. On the other hand, traditional hand-made carpets have a long production cycle and are not competitive with woven carpets in terms of price and production capacity. "Weaving a foot loses a foot" is a portrayal of the serious upside-down of Beijing palace carpets and value in the process of marketization in China. The labor cost and high maintenance of hand-woven carpets are also the main factors that make Beijing palace carpets unsustainable. [1]

The daily necessities of Beijing palace carpets are positioned as indoor furnishings, with high prices, low output, and lack of irreplaceability; as handicrafts, they have a single form of expression and product, and they have no competitive advantage compared to industrial products in price and production capacity. The Beijing palace carpets are positioned as the collection of high-end artworks. The value is not easy to judge at this stage, and there is a lack of room for appreciation in the short term. The panjin carpets, which can be regarded as artworks and collectibles that worth more than a million yuan, are few in number due to the limited capacity. The high price makes the market share of Beijing palace carpets extremely limited.

\subsection{The Theoretical Foundation for the Research and Development of New Products of Beijing Palace Carpets Is Weak, the Historical Origin and Cultural Heritage of Palace Carpets Are Not Sufficiently Explored, and the Design and Creation Concepts and Weaving Techniques Need Further Innovation}

The inheritance of the Beijing palace carpets still follows the oral teaching of the masterapprentice system by the craftsmen. The development of the creation formula and artistic style benefited from the practice and exploration of several generations, and there is no systematic theoretical system so far; The stylized composition form (metrical modern style, spray style), and stylized patterns (a large number of arts and crafts, architectural paintings, sculptures, etc. in the Ming and Qing dynasties) formed the unique artistic style of Beijing palace carpets. How to break through the stylized pattern of palace carpet design and creation, which not only retains the distinctive artistic style characteristics of traditional Beijingstyle carpet patterns, but also conforms to the current fashion aesthetic trend, has always been a bottleneck in the development and inheritance of palace carpets; at the same time, limited by the company's production scale, research and development conditions, and policy mechanisms, 
the speed of research and development of new products of palace carpets lacks the ability to quickly respond to changes in market demand and the diversification requirements of the international market. [2]

\subsection{Inheritance of Beijing Palace Carpet Weaving Skills}

Beijing palace carpet weaving skills have many processes, and the skills are not easy to master. The inheritance requires high cultural literacy and accumulated practical experience. At this stage, the main inheritance should be aimed at the employees of Beijing Huafang Carpet Art Co., Ltd. On the one hand, affected by career prospects, treatment, etc., young people treat carpet weaving careers as useless, and there is a fault in the inheritance. On the other hand, because Beijing palace carpet weaving has not formed a systematic theoretical system, it is still taught in a more traditional way of oral teaching, and the effect of talent training is not good.

"Carpet maker, carpet maker, sitting on the board, with one stroke of the knife, the head shook", this folk proverb is a portrayal of the professional characteristics of carpet weaving. Affected by the modern carpet industry, the market space for traditional handmade carpets is constantly being eroded. It starts with responsibility and abides by feelings. Carpet makers in the new era stick to the cultural heritage and handmade traditions, but face the embarrassing situation of no successor.

\section{PROTECTION AND INHERITANCE STRATEGY OF BEIJING PALACE CARPET WEAVING SKILLS}

\subsection{Building an Intangible Cultural heritage and Telling a Good Brand Story with the Help of National Strategy}

The cultural and ecological dilemma faced by Beijing Palace carpet weaving skills is not an exception. The "live rheology" of intangible heritage technology has strong social and contemporary characteristics. It is separated from the "protection" inheritance of the living soil and can only weaken the vitality of intangible cultural heritage. The shallow level of the cultural ecological dilemma is due to the lack of cultural consciousness caused by the aesthetic pursuit of western fashion. The analysis of deep level is the decline of the traditional lifestyle with traditional Chinese culture as the core against the background of economic globalization. In the context of national policy support, intangible cultural heritage does not lack exposure, but lacks audience cultural awareness and consumption transformation. The intangible cultural heritage protection plan in "14th Five-Year Plan" clearly pointed out that adapting to the trend of media integration and expanding intangible cultural heritage communication channels. On the one hand, through the Internet, digital technology, big data technology, etc., different media forms and multiple expressions can be used to enhance the communication effect, strengthen the people's cultural consciousness, and scientifically carry out production and industrialization protection to create soil for the survival and development of intangible cultural heritage in the context of modern society. On the other hand, intangible cultural heritage protection units must actively adapt to the new cultural ecology. The inheritance of "authentic" does not mean that they are complacent and conservative. They must also innovate their operating models and creative concepts, and focus on the content of the times with the breath of life and the aesthetic elements that reflect the characteristics of the times, to open up new forms of survival and new products for Beijing palace carpets, and give them lasting vitality under the premise of innovative development.

\subsection{Building a New Model of Diversified Product Systems, Diversified Production Methods, and Inherited Intangible Cultural Heritage Industrialization}

Beijing palace carpet weaving skill is a national intangible cultural heritage project, and Beijing Huafang Carpet Art Co., Ltd. is the protection unit of the "Beijing Palace Carpet Weaving Skills" project, which is a core advantage that other companies do not have. Due to the constraints of policy mechanisms, capital, production capacity and other aspects, the phased strategy can concentrate superior resources, take the route of customization and high-end artwork around the Panjin process, and achieve good results in brand promotion and product recognition. However, such high-end products appearing in the form of "soft gold" are really difficult to support the healthy 
development of enterprises. Without the advantages of raw materials and large-scale production, a new business format that adapts to diversified, various, and personalized products to meet the needs of different application scenarios has become an inevitable choice, which can form an effective connection between supply and demand. First of all, it is necessary to focus on the core skills of "fleece planting and plate gold", centering on the reproduction of ancient carpets, such as the reproduction of palace carpets from the Palace Museum, and high-end customization, to create value-preserving and value-added handmade boutique palace carpets in an "original flavor". Secondly, there is also a necessity to dig deep into the field of Chinese-style home furnishings, dig deep into the palace culture and traditional auspicious culture, and create a series of products based on traditional home furnishings and new Chinese furnishings. [3] Third, it is a must to follow the practical functions of the carpet, develop new crafts and new materials, do a good job of functional expansion, and develop new application scenarios. On the one hand, it is necessary to pay attention to the hot IP of film and television and culture, integrate consumption motives such as fashion, feelings, and rigid demand, and use the hot IP to leverage the purchasing power of the audience. On the other hand, through brand authorization, it is also necessary to absorb highquality social design resources, create cultural and creative products based on Beijing palace carpets, and enrich the palace carpet product line. At the same time, the traditional auspicious culture is used as the entry point for the research and development of the small-scale cultural and creative products of Beijing palace carpets. Focusing on the miniaturization of palace carpets and the diversified practical functions of palace carpets, traditional craftsmanship is used to solve the problems in modern life, and the auspicious culture of traditional culture is used to enrich people's spiritual homes, and "carpets" are used as a guide to expand the radiation role of traditional culture in life.

\subsection{Exploring the Cultural Heritage, Innovating Excellent Traditional Culture, and Realizing the Creative Transformation of Traditional Culture}

Beijing promotes the basic pattern of the "four cultures" in the mid-to-long-term plan (2019-2035) for the construction of a national cultural center, and clearly proposes that "it is a must to use the long-standing ancient capital culture, the rich and heavy red culture, the distinctive Beijing-style culture, and the flourishing innovation culture, to continue to enhance the cultural depth and thickness of the construction of core values". [4] Beijing's traditional culture is a typical combination of royal culture and secular culture. Beijing palace carpets are both royal and folksy. They are an important representative of traditional handicrafts in Chinese court art. The court art collects the design ideas and design rules contained in the Chinese national culture, etiquette and custom culture, and provides an effective theoretical basis for the innovation and transformation of Beijing's traditional culture, so as to better promote the inheritance and development of China's excellent traditional culture. [5] It can make the traditional skills have freshness, inject the age of the old objects, and present them in a young way, so as to produce a better communication effect. [6] How to make intangible cultural heritage "integrate into society, into life, into the times", co-branding, grafting, industrial upgrading, etc., these "crossborder" vocabulary are full of creativity and frequently create models in intangible cultural inheritance projects.

\subsection{Giving Full Play to the Advantages of Higher Education Resources, and Using Palace Carpet Weaving Skills as a Characteristic Carrier of Aesthetic Education and Labor Education}

It is of great significance to actively cooperate with universities and scientific research institutes to make up for the shortage of design and $R \& D$ reserves and creation bottlenecks through horizontal projects and take advantage of the scientific research advantages of universities. At the same time, with the advantage of the university platform, there will be a must to organize student competitions on the theme of palace carpet design and promotion, explore high-quality creative resources, and expand brand influence; with the help of university discipline construction resource advantages, it is necessary to gradually build a palace carpet skill inheritance and training system, and form a systematic training plan from cultural cultivation, design innovation, and skill inheritance. At the same time, on this basis, it is a necessity to develop experience courses in multiple scenarios, forming multiple types of course packages suitable for primary, secondary, and university levels. The inheritors of intangible cultural heritage participate 
in the education and teaching of intangible cultural heritage practice courses, and they can use palace carpet weaving techniques as the characteristic carrier of aesthetic education and labor education to further dig the intangible cultural heritage resources of Beijing palace carpets and promote multidimensional development.

The inheritance and training of talents of palace carpet weaving skills should strengthen the toplevel design, which can be oriented to vocational education, undergraduate education and postgraduate education according to the actual needs of different positions. According to the educational characteristics of different types of colleges and universities, cooperation needs to be carried out around theoretical system construction, design research and development, and skill inheritance. For example, the inheritance of craftsmanship can take the form of order training, and learn from the German dual school-enterprise co-education method to carry out talent reserve training in vocational colleges to solve the dilemma of long period of technological inheritance training and no successor.

\section{CONCLUSION}

Since the 18th National Congress of the Communist Party of China, General Secretary Xi Jinping has made a series of incisive expositions on Chinese traditional culture. Intangible cultural heritage contains the cultural genes, spiritual characteristics, and values of the nation. The core and ultimate goal of intangible cultural heritage protection lies in the inheritance and promotion of its intrinsic cultural value. The Beijing palace carpet, one of the eight unique skills of Yanjing, was once an important part of the furnishings of the royal palace. Not only did the layout of the ornaments, the combination of ornaments, and the combination of colors create the characteristics of "words must be meaningful, meaning must be auspicious", but also did a unique artistic language have been formed in the weaving process. The design ideas and design rules contained therein provide an effective theoretical basis for the innovation and transformation of traditional culture, thereby promoting the inheritance and development of China's excellent traditional culture.

The inheritance of intangible cultural heritage is not static. It is necessary to respect and inherit the authentic elements contained in it, and innovate the design and weaving skills; products need to not only meet the needs of cultural belonging, but also meet the aesthetic needs of the times, as well as meet the needs of practical functions. These can be the ways to allow Beijing palace carpet weaving skills truly "integrate into society, into life, into the times", and better play the role of inheriting the excellent Chinese traditional culture.

\section{AUTHORS' CONTRIBUTIONS}

Jiang $\mathrm{Xu}$ determined the research theme and wrote the paper, and Jiang Baitao is responsible for the revision and editing.

\section{REFERENCES}

[1] Xu Tianqi. Beijing Carpet in Historical Dust [J]. Textile Science Research, 2013 (2) : 2. (in Chinese)

[2] Lu Hongqi, Chinese Ancient Carpet [M]. Beijing: Knowledge Publishing House, 2003 (2): 192-201. (in Chinese)

[3] Yuan Hongqi, Liu Baojian, Carpets in the Collection of the Palace Museum [M]. Beijing: Forbidden City Publishing House, 2010 (6): 11-27. (in Chinese)

[4] Medium and Long-Term Plan for Beijing to Promote the Construction of National Cultural Center (2019-2035).

[5] Wang Zilin, Ming and Qing Imperial Palace Furnishings [M]. Beijing: Forbidden City Publishing House, 2011 (5): 13-17. (in Chinese)

[6] Qiu Yu, Li Sitong. Wedgwood brand marketing design research. Digital Design (part 1) : 2021-02-15. (in Chinese) 